COCKIES V. BLOCKIES:

CULTURAL CONSTRUCTS IN THE ANALYSIS OF RURAL CONFLICT

Roger T. W. Smith

\begin{abstract}
Based on an ethnographic study of rural change, this paper examines the theoretical and empirical contexts for friction between traditional farmers and lifestyle block holders in a small Lower Northland farming district. It describes how farmers' subdivision and sale of land for smallholdings has attracted a steadily-increasing number of urban migrants, principally from nearby Auckland. Conflicting culturally-based understandings of rurality by farmers and blockholders manifests in behaviours that produce tensions between the two groups. Each values the rural environment for different reasons and in different ways. The result is that farmers view blockholders as a challenge to their still dominant culture.
\end{abstract}

\title{
INTRODUCTION
}

Seven kilometres west down Oneriri Road from the Lower Northland township of Kaiwaka an imposing set of high gates - painted black and with no latch - closes off a sealed road that winds down toward a small lake then up a steep hill, disappearing from view around the hill's flank and into a dense patch of bush. A secondary road branches off the main drive, looping around the other side of the lake. Along both sides of this secondary road are whitepainted posts marking the position of boundary pegs that describe the perimeters of individual blocks of land. Between the posts are signs giving the number of the block and its size. There is no mention of price. Many of the signs bear 'Sold' stickers. If you were to follow the main drive up the hill you would find many more of these signs. There are fifty in all, fronting the roads that web this $202 \mathrm{Ha}$ enclave, formerly a drystock farm.

This is Takahoa Bay, a residential farm-park developed specifically for the well-heeled seeker of rural peace and quiet. Prices for the choicest hilltop 
sections are as eye-watering as the prevailing south-westerly winds that scour these riverside slopes. For a spectacular view of the Otamatea River and the pastureland that rolls northward from the farther shore of this arm of the Kaipara Harbour you can pay upward of half a million dollars.

This is the upmarket crest of the wave of lifestyle block developments that have encouraged a small flood of urban migrants into the Oneriri peninsula during the past decade. The blockholders are the most visible evidence of the fact that the peninsula is no longer purely a farming district. Though most of the landscape is dotted with cattle - its main function is still to produce food - Oneriri is also a place to live and, for those whose weekdays are spent working in the city, a place to relax and to play.

At the human level in Oneriri there is a paradox that has farmers subdividing land for sale to 'townie' blockholders they would sooner not have as neighbours. The differences between blockholders and farmers are the differences between urban and rural, town and country, and for some farmers the codecontrolled gates of Takahoa Bay are unwelcome signifiers of the differences. For people who seldom lock their doors the gates are an affront; they say they are not trusted by those who are to live behind them. The gates also carry another message for the farming fraternity. Said one: 'Those gates are all about social status. We can do without that'. The farmer thought for a moment then found a solution: 'If the Maoris want to pinch those bloody security gates they can do so with my blessing. I'd even give them a hand'.

This paper explores differences between the farmers - the cockies - and the lifestyle ${ }^{1}$ block owners - the blockies - of the Oneriri peninsula, the latest of many rural areas fringing New Zealand's main centres that are undergoing profound social and physical change. These areas have long been the target of high-income urbanites seeking retirement acreage, small farm holdings, or blocks for weekend recreation. The improvement of State Highway 1 north of Auckland City coupled with the spectacular water views from most parts of Oneriri - one of the many peninsulas fringing the Kaipara Harbour - has, particularly during the past five years, encouraged townsfolk to invest in land there.

Cockies v. Bockies as a title implies that a state of conflict exists between the two principal groups of residents of the peninsula. Conflict exists, but it is seldom manifested in any form of aggressive behaviour, or even by the withholding of social niceties. Because the population of the Oneriri peninsula is sparse in urban terms - about 350 all told - people tend to rub along. How- 
ever the narratives of both farmers and blockholders indicate clearly that each group has different cultural understandings of Oneriri as a place-based community undergoing rapid change. In cultural terms the Oneriri landscape is becoming a contested one. For example, the current programme of widening and sealing Oneriri Road, which is the main artery to the end of the peninsula, is not welcomed by all. The progressive upgrading is needed to meet the traffic increase as more and more blockholders move in. Farmers on the stillunsealed part of Oneriri Road believe a sealed road will encourage further subdivision. This will also mean more speeding townies endangering stock moving on the road.

The blockholder sin that raises the greatest contestation though, is farmers' perception that blockholders fail to care properly for the land they have bought. This stems principally from opposing views between the two groups on the use of herbicide sprays to control weeds. Blockholder activism in many parts of New Zealand has resulted in bitterly resented curbs on farmers' spraying practices. Blockholders in Oneriri for their part cite the continued use of sprays as a matter of major contention. They also complain about the driving of sheep and cattle on the roads and the roaring and screaming of the McDonalds-destined bulls that have become the mainstay of farming on the peninsula.

Use of land and its care, as I will argue, is the major manifestation of cultural difference between cockies and blockies in Oneriri. Because farmers represent the dominant culture of the peninsula, and as owners of most of the land are most subject to the effects of change, this paper focuses on them: it is their way of life that is threatened. The recently-arrived blockholders have their cultural roots elsewhere; they see Oneriri through different eyes.

This paper is based on data gathered from twenty-two farmers and twenty-six non-farmer residents of Oneriri - both male and female - for the principal research component of my M.A. in Social Anthropology. The research, spread over a year beginning in November, 2002, employed three methods of data gathering: life history collection, participant observation and interviews using question guides. All life history narratives and interviews were tape-recorded and later transcribed. The quotations from participants that appear in below were drawn directly from these transcripts. ${ }^{3}$

The farmers who contributed to the study are representative of most on the peninsula. They are within a few years of retiring, but some, out of step with the baby-boom population bulge, are in early middle-age, still struggling with 
the costs of farm succession. All mourn what they see will eventually be almost an end to traditional farming, as they understand it, on the peninsula. They accept that farm parks and small blockholdings will eventually begin to threaten pastoral farming as the dominant land use. In this expectation they are likely to seek to maximise the potential return they can gain from their land by selling their farms, or parts of their farms, specifically for such developments. Several have recently done so. ${ }^{4}$ The sale of whole farms or substantial acreage for traditional farming purposes is likely to diminish, though not disappear. Some land is simply not suitable for smallholdings. While such sales add only minimally to the population and are thus less significant in their effect on social change in the peninsula than, say, the Takahoa Bay development, it will probably be the retention of this land in agricultural production that will preserve the rural character of the Oneriri landscape that has developed over the past 145 years.

\section{CULTURES OF RURALITY}

There is a wealth of literature that demonstrates that 'rural' is a complex cultural construct, rather than merely a spatial nomination (see Cloke, 1983; Share, et al, 1991; Hughes, 1997; Cloke and Little, 1997; Boyle, et al, 1998). Many writers nominate culture as a determinant in interpreting human behaviour and relationships in rural communities. The influence of the rural idyll is frequently suggested as a reason for perpetuation of rural sentiment.

Understandings of the rural idyll, or Arcadia ${ }^{5}$ are generally associated with the motivation of rural residents to seek to migrate to the country (see, for example, Swaffield and Fairweather, 1998; Little and Austin, 1996; Matthews, et al, 2000; Boyle and Halfacree, 1998; van Dam et al, 2002). The rural idyll presents happy, healthy and problem-free images of a rural life safely nestling with both a close social community and a contiguous natural environment (Cloke and Milbourne, 1992:359).

Lambert (2003:25) says urban dwellers also persist in sentimentalising the rural past, hoping to rediscover the simpler life of the country-dweller. Arcadian ideals such as these commonly emerge in overseas studies of motivations for migration to rural areas. Swaffield and Fairweather (1998) found that in New Zealand too, the Arcadian ideal continues to have a major influence upon migration to rural lifestyle smallholdings.

Cultural constructions of the rural and its representation are rooted in a set of assumptions, expectations and values (Cloke and Little, 1997: 279). People 
derive their own sense of the rural, reinterpreting dominant images through their own cultural practice (Crouch 1992, cited in Jones, 1995:39). The rural, therefore, is a 'dynamic and unstable' (Hughes, 1997:124) social construction and an arena in which the hopes, values and prejudices of social groups can be played out (Murdoch and Day, 1998:191). Cloke and Milbourne extend these notions, suggesting that some of the problems experienced in rural lifestyles arise from conflict between cultural constructs of rurality: conflicting cultural norms and practices (which they refer to as 'competences') and symbols (1992:360). They point out that cultural meanings of rurality are circulated at national, regional and local levels, and at the local level any composite construction of the rural will inevitably include individuals' own experiences of the rural.

The farmers and blockholders of Oneriri hold different culturally-based views of the rural as they experience it. As long-term occupiers of land devoted principally to food production, farmers hold largely similar notions of how land should be used and cared for, and their place in a traditional farming community. Blockholders are culturally more diverse than the farmers and hold widely divergent views about their place in the rural and how they should live in it. In cultural terms both groups make different assumptions about the rural, have different expectations of rural life, and are guided by different values in their experience and understanding of rural living. As will be described, this is the source of the differences that serve to keep cockies and blockies in a state of mutual social exclusivity

\section{CONTEXTS OF HISTORY AND REFORM}

The existing culture of Oneriri farmers is, especially for the older families, deeply rooted. From 1860 the peninsula was progressively settled by Europeans and farmed, initially by a handful of families. The original farms, or 'runs', some of them as much as 4,000 hectares, or nearly 10,000 acres, ${ }^{6}$ were accumulated through a combination of direct purchase, and lease followed by purchase, from Te Uri O Hau hapu of Ngati Whatua (Smith, 2002 [1910]:333).

For about four generations, as these families grew, they subdivided their runs in accordance with a strictly patrilineal system of succession: sons took over the farms, daughters found husbands elsewhere. Land was bought and sold between the families as needs changed. In time farmers from outside Oneriri bought farm blocks from the older families and all prospered during the farming boom of the 1950 . 
By the mid-1980s the picture had changed. Abolition of farm subsidies as part of a government programme of radical neo-liberal deregulation, coupled with diminishing returns for farm produce, caused a massive disruption of the economics of family farming. Nationally, farmers with large mortgages were hit hardest as incomes withered and interest rates climbed. Strategies employed by farmers throughout New Zealand to survive the resulting downturn initiated a process of change in farming practices that led eventually to higher value products (for macroeconomic views of this time see, for example, Gouin et al, 1994; Wilson, 1995; Levett and Pomeroy, 1997; Federated Farmers, 2002; Johnsen, 2003). This now enables the national agricultural industry to compete in international commodity markets distorted by foreign domestic subsidies and punitive tariffs.

Throughout the country the structural reforms initiated by the government deepened and broadened, and vastly accelerated, the usually steady process of rural change. The degree of change created pressures widely seen at the time as intolerable, but the agricultural industry very quickly learned to do without government inputs.

Oneriri farmers suffered less than most from the downturn that followed the agricultural reforms. Few of these farms at the time carried big mortgages and the farming families were long accustomed to coping with the lean periods of a naturally cyclical industry. However, the long-term effects of change in the agricultural sector were paralleled by social and structural changes that impacted on the conservative farming families of Oneriri. One of those changes has now brought to an end the dominance of the traditional farmers: their sons no longer want to take over the farm, nor are their daughters interested. Not only is farming frequently seen by much of this latest generation as lacking the challenge and rewards offered by other, urban-located, careers, but escalating land prices in Oneriri mean they have little chance of being able to afford to buy the family farm. To retire with any measure of financial comfort, their parents are facing the prospect of selling their farms to non-farmer others.

TRAJECTORY OF CHANGE

A regional profile of Northland prepared by Statistics New Zealand concludes with a brief comment that encapsulates the relationship between Oneriri and Auckland, and its consequences for the change that is transforming the peninsula today:

...the southern part of the [Northland] region has the potential to be 
affected by the burgeoning growth of Auckland, and it is possible that the future Auckland population will encroach upon the region (Statistics N.Z., 1999:10).

In the six years since those words were written, smallholdings in Oneriri have sold steadily. A few have become olive groves or grow exotic flowers, but most now have a house and a few head of stock. For the farmers the blockholders are an ever-increasing reminder of the nearness of New Zealand's most populous city. The demand for smallholdings offers them big returns from subdivision, but it also means the end of the sustaining farm lifestyle and their probable departure from a district that in many cases has been called home by five and even six generations of a family.

In Oneriri the subject of subdivision and its effects is never far away when farmers get together. They recognise a certain inevitability about the process that is transforming Oneriri from a tight farming community into a haven for urban migrants. The 'desirable' status the peninsula has so obviously acquired is following the certain pattern established by Franklin District and other now semi-rural areas near Auckland. Farming will continue in Oneriri as the dominant land use for the foreseeable future; there is no suggestion or likelihood that its landscape will ever become a suburban one. Though the landscape will be modified by new landowners over time, the principal changes at present are social ones, resulting from a classic pattern of land-use change.

RURAL-URBAN FRINGE, SHADOW OR HINTERLAND?

For all but a few patient souls, Oneriri is not yet within comfortable dailycommuting time of Auckland, but the patterns of development that can bring a once-distant locality within the orbit of the city fringe are firmly in place between Auckland and Oneriri. What was once a clearly identifiable edge separating the city from the countryside has become blurred. The development of better and more extensive roading systems around and extending from the city and a more mobile population pursuing both real and imagined delights of living outside the city means that, apart from local political definitions, it is difficult to say where the city stops and countryside begins. Instead, there are a variety of environments radiating from the city centre, each segueing to the next. Different terms such as 'fringe, 'inner fringe', 'rural-urban fringe,' 'urban shadow', and 'the exurban zone' are used sometimes interchangeably, sometimes to identify quite separate areas, but usually overlapping to some degree (Martin [1975a], cited in Bryant, et al, 1982:11). 
In their exhaustive discussion of what they call 'the city's countryside' - that area around cities in which various processes of change in land use occur - Bryant et al. make the point that it is not so much the extent of the resource base contained in the countryside around cities that makes it critical to society in terms of food production, recreation and so on, but rather the fact that the land and its resources are subject to competing, often conflicting, demands. They point out that the physical environment in which these zones of transition develop may vary significantly between cities, cited in Auckland's narrow isthmus as an example of a 'constrained' location. In a diagram somewhat like a cross-cut onion they apply different terms to rings or zones radiating out from the central built-up area of the city:

The inner fringe is characterized by land in the advanced stages of transition from rural to urban uses - land under construction, land for which subdivision plans have been approved. The outer fringe which, together with the inner fringe forms the rural-urban fringe, is an area where, although rural land uses dominate the landscape, the infiltration of urban-oriented elements is clear. Further out... may be an area of urban shadow, an area where physical evidence of urban influences on the landscape is minimal, but where the urban...presence is felt in terms of...a scattering of non-farm residences. Finally, the urban shadow merges into the rural hinterland; even there metropolitan and urban influences do not stop - urbanites may still own properties for weekend retreats and cottages, and the rural people themselves certainly cannot help but be influenced by urban values and ideas that are transmitted through the media (Bryant et al 1982:13-14).

In this theoretical context Oneriri can be seen as sited in the urban shadow, where farming predominates, but the urban presence is signified by non-farm residences.

\section{LAND USE CONTROL}

As long ago as 1946 a minimum subdivisional requirement of ten acres was fixed by the Counties Act, to apply in rural areas outside a borough or town district. Any person who wanted to subdivide land into lots smaller than ten acres had to submit a scheme plan to the local county office showing the proposed subdivision.

Mawhinney's (1974) study of ten acre subdivisional lots in Manukau City and 
Franklin County found that the increasing value of farmland in these close-toAuckland areas was the principal reason nominated by farmers for subdividing their land. Though today the Resource Management Act places land use control firmly in the hands of territorial authorities, Franklin District Council (formerly Franklin County) is still trying to rein in small-block subdivision. A District Plan change (September, 2003) attempts to restrict subdivision to lower quality land, leaving land with high grade soils for agricultural use. The council notes (2003:2) that a key issue is the effects of an increasing 'lifestyle' population on a largely rural area. Many of the newly created lots are used for lifestyle purposes only and not for the rural activities for which they gained subdivision approval and this has often resulted in rural residents buying larger properties than they want or can manage.

This parallels the Oneriri experience where many blockholders have purchased much more land than they need, simply because any landowner can subdivide, as of right, blocks of 10 acres or more. Anything less requires a much more complicated and lengthy process. Both farmers and blockholders agree that 10 -acre subdivisions should be a thing of the past, mainly because 10 acres is an area of land that is too small to actually farm other than for intensive horticulture, and too big to otherwise look after, leading to the stereotypical tidy country cottage on a fenced-off quarter-acre, surrounded by nine and three-quarter acres of weeds. Both farmers and blockholders broadly favour the farm-park concept where each landowner has a small residential block well distanced from others and a collective interest in the balance of the land, which remains in production. Each landowner effectively has 10 acres but needs only to maintain a residential section. Kaipara District Council has recently approved two such developments in Oneriri; a third, of some 1,600 acres, and preliminary planning for 140 houses, is currently before the council.

\section{COMMODIFICATION}

From a farming perspective, urban migration may offer an opportunity to capitalise on the accompanying surge of land values - especially when the farm's economic viability is threatened. In some circumstances the sale of a small part of a farm enables farmers to remain agriculturally competitive as they intensify farming operations. Sale of the farm altogether enables them to move farming operations to cheaper land (Furuseth and Lapping, 1999: 8,11). In both of these circumstances the change of land use is likely to have a flowon effect in value terms to other farming properties in the district. The influx of urban migrants to a farming district in pursuit of perhaps idealised percep- 
tions of rural living inflates the value of farmland far beyond any valuation based on productive capacity.

Nowhere is this more obvious than in Oneriri. In late 2003, a 58-acre block sold for $\$ 1.2$ million - more than twice the price it was bought for three years previously, and an 80-acre block, all in pasture, sold for $\$ 2$ million. Recently a 1600 -acre farm sold for more than $\$ 7.5$ million. As farming propositions none would be worth even a third of the price it sold for, but each of these properties is bordered by the Otamatea River, affording direct boat access to the Kaipara Harbour. Even land without water frontage is at a premium as long as it has a water view.

In moving from urban places to the countryside, in-migrants in effect 'purchase' the experience of being in a rural community and landscape. Halseth (1999:164) says this purchase of an experience or of a lifestyle occurs just as a consumer would purchase other goods, services or activities. Non-rural people attach their own perceptions and imagery to rural places (Halseth, 1999: 164). Developers and real estate agents are well aware of such perceptions: 'It is the idealized image as much as the actual landscape which has been turned into a commodity for sale through the real estate market' (1999: 166).

\section{CULTURAL DIFFERENCES}

Understandings of 'rural' in Oneriri are clearly experientially based. Both farmers and smallholders in Oneriri speak of the rurality they know, rather than an unattainable ideal. One fundamental difference between each group's cultural perceptions of the rural arises from the fact that, through their land management practices, farmers have created the landscape which is experienced - even consumed - by their blockholder neighbours. The way countryside has been shaped and reshaped by human occupation and use is the practical expression of the cultural understandings of a succession of farmers. The landscape, over time, becomes a palimpsest, each occupier leaving some tangible imprint, with the reshaping deriving from socially and economically driven change. Examples in Oneriri are the remnants of homesteads and gardens close to the river, abandoned when roads became a practical alternative to river transportation, and milking sheds with their concrete-paved yards standing unused on farms converted to bull raising.

As foreshadowed, there is a wide diversity between farmers and blockholders in their understandings of key elements in the constitution of the rural which contributes to the maintenance of cultural difference between them. 
For example, both groups agree that the rural environment affords them the quality of life they desire, but farmers define their lifestyle directly in relation to the practice of farming whereas blockholders analyse it from more intangible viewpoints: contrast with the urban, personal safety, isolation from other people and scenic beauty. Conversely, attitudes of farmers to the city are predictable: most have a strong aversion to all that the city represents in terms of crowded living and the heavy traffic and bustle. Though the blockholders have in most cases turned their backs on the city as a place to dwell, they do not share farmers' detestation of it, possibly because some still work there, others because it is where friends and family live.

Farmers fundamentally view themselves as just that: farmers, and have little inclination to elaborate or explore further. The few who do reveal different attitudes to the farming life seem to reflect varying degrees of regret for having chosen - or having been thrust into - a farming career. In the rural context most blockholders cling to their largely urban origins and living style. The general view is that the country satisfies some cultural elements they believe they need, but that is the extent of their engagement with it. Theirs is a consumption-based, rather than production-based, understanding of rurality. This is borne out by a generally only partial attachment to the land they live on, whereas farmers attest to deep and abiding relationships with their land based on familiarity and, in many cases, historical family ties.

Because almost all blockholders maintain their urban links, the question of whether they see rural living as better than urban is irrelevant; their lives encompass both milieux. Some see the more or less general lack of facilities ranging from medical care to shops, lack of employment opportunities and isolation as disadvantages of rural living. Despite these disincentives, countermigration seems to be a consistent feature of population movement in New Zealand (Waldegrave and Stuart, 1998). It is the cultural differences between cockies and blockies and the lack of a community of interest that results in them not always seeing eye to eye. While this is not necessarily a disincentive to leaving the city to live in the country, blockholders regard farmers' views of them as a negative, but unavoidable aspect of rural living.

CONSTITUTING OTHERNESS

One of the farmers contributing to this study had this to say about smallholders:

There's good lifestylers and bad lifestylers. The good lifestylers will 
take an interest in everything that's going on around them, and take an interest in trying to keep their place looking smart. The bad lifestylers are the ones that cause trouble, pinpricking about everything that's not necessary. They've got to remember that we've got a farm to run, and run the best way we know how, and I suppose spray must come into that. I know we've got to be careful with spray, but some of them go a bit silly about it.

This pronouncement is notable for a number of reasons. The first is that it embraces the two most frequently voiced criticisms that farmers direct at blockholders - that few control weeds on their land ('keep the place looking smart'), and that they are almost certain to object to farmers' use of herbicides. The second is that the worth of the 'bad' blockholders' opinions is minimised, dismissed as 'pinpricking' and 'not necessary'. The third element of note is that the whole tone of this comment clearly identifies blockholders as 'other' to the speaker, especially in terms of farming knowledge ('farm ... the best way we know how'). To sum up this analysis, in this farmer's reckoning blockholders are clearly Others who know little or nothing about farming. There is thus a clear discursive distance between this farmer and the people who are 'othered'.

Twenty years ago, traditional family farming was the dominant culture of the Oneriri peninsula, a situation that had changed little for more than a hundred years. Even 10 years ago there were few blockholders, but more recently their numbers began to build steadily. Today blockholders by far outnumber farmers, but the farmers are still effectively the dominant culture of Oneriri for two reasons. First, almost all of the farmland of the peninsula is devoted to pastoral farming. Though a breakdown of land use between farming and smallholding is not available, Kaipara District Council's planning maps showing individual titles indicate that smallholdings occupy less than five percent of the peninsula. Second, farmers constitute a readily identifiable and clearly visible sector of Oneriri's population by virtue of their occupation; there is little commonality among blockholders in terms of land use and occupation. For much of the farming community the otherness of blockholders manifests in two categories: social relations and farming practice.

SOCIAL RELATIONS

Some farmers volunteer excuses or reasons why they have little or no social interaction with blockholders. Some say that smallholdings change hands so frequently they cannot keep up with who owns what; others plead pressure of 
work leaves them no time to forge new friendships. Other farmers make no excuses; they say they simply prefer to spend their social time with the people who share their farming interests.

Blockholders clearly signal that they regard farmers as Other in the social sense by the way they objectify them almost as a separate species. Possibly this is mainly because so few know any farmers. Those who have made the effort to try and meet farmers socially often state they feel there is a barrier of some sort put up by the farmers. One blockholder used the term 'like a sort of veneer' to describe the feeling; another just said bluntly 'there is definitely a cleavage between us'.

One element contributing to the social divide between farmers and blockholders may possibly reside in a reluctance on the part of farmers to seek new friends outside their existing social networks. This notion resonates with survey evidence from Newby et al. (1978) which shows that farmers' social networks are extremely confined. In general, they conclude, farmers simply do not have non-rural, non-local friends. They rarely meet socially with people from outside agriculture (cited in Murdoch, 1995:1222).

\section{FARMING PRACTICE}

In terms of land use and the practice of farming, many Oneriri farmers maintain a rigid distance from blockholders, exemplified by the attitude of the farmer quoted above. A minority recognise that those blockholders who run stock or otherwise farm their blocks need time to learn agricultural skills. They are, therefore, more tolerant of the shortcomings vilified by their farming cohorts. The plaints of the less tolerant have become a credo:

They have got to learn about the spraying. They need to appreciate it has always been done and they can't expect it to be stopped just because they've come. Of course, all farmers are considerate about that anyway. We would never spray when it is blowing over the neighbour.

Some of the people who've moved here have moved without a mission. They've moved onto properties because they've either had a redundancy or [an inheritance], and they don't work, some of them. They don't want to do much so they're not going to contribute much to a community; usually they will be passengers. 
There are [blockholders] who appreciate the country lifestyle and those who abuse it. A lot are ignorant about looking after animals and getting rid of weeds. A lot are ignorant about the soil; if you look after the soil right it's going to grow good grass.

It's getting out of line a bit, the encroachment of lifestyle blocks on our farming. We have to be so careful [about spraying] now. We don't use a lot of it now, but I used to use a couple of hundred litres of $2,4,5 \mathrm{~T}$ a year just to keep gorse under control.

The blockholders don't want to involve themselves in the community. They tend to just keep to themselves and their little pockets of friends.

There's the ones that come into the community and then expect city conditions. They should accept the community and the farming practices that go with it without [behaving in a way] that makes it hard to be neighbourly and get on.

Surprisingly, most blockholders are reasonably sympathetic to, and echo, farmers' concerns:

I wouldn't say that the blockholders are incapable of looking after their blocks, but there are some that don't seem to have made much progress. Some of them now have more thistles and gorse spreading on them than they've ever had.

There are lifestylers who move here without a penny left over and can't improve their lot in any way because they can never get on top of the financial burden from buying in here. Their blocks obviously suffer.

A lot of people bite off more than they can chew; they don't keep the damn weeds down and that really breeds resentment among the farmers.

I would like to think that when we leave [this land], we leave it better than when we picked it up. I would also like to think that what I do doesn't detrimentally affect my neighbours and vice-versa.

Land has got to be looked after responsibly and sensitively. If it is 
overrun with weeds that is both irresponsible and insensitive.

At the same time, smallholders can be critical of what they see as poor farming practices in Oneriri:

I don't see the land around here being abused, but in terms of good farming practice, there hasn't been a lot of it necessarily.

It seems to me there are parts well looked after and parts that aren't. There is a lot of gorse and other weed about. My father always said you could tell a good farmer by looking at his fences. There are an awful lot of bad fences on the peninsula.

It's sad the Oneriri farmers don't look after the land well. I don't know whether it's a matter of economics; perhaps they can't afford to pay more attention to their land.

Farmers have this grass mania. Every blade of grass counts, doesn't it? They still farm the old ways; they won't put up shelterbelts because they cut down their grazing.

I hate to see animals standing out in the baking sun when [the farmer] could plant a few trees and let the animals have a modicum of comfort.

\section{GOOD NEIGHBOURS, BAD NEIGHBOURS}

New meanings and cultural understandings of the rural challenge those of the existing dominant culture. New meanings, values and practices are continually being created and it depends on the degree to which these are incorporated into the dominant culture as to whether opposition leads to direct and sustained cultural conflict (Cloke and Milbourne, 1992). The expression of cultural opposition tends to focus on unimportant, or only marginally important points of conflict:

Where they exist, it is crucial to gain an understanding of the symbolic nature of cultural oppositions, whereby discord between different lifestyles in the same place may be brought about by the lack of symbolically crucial but materially straightforward cultural competences which are not being observed by one group of people to another (1992:366). 
In Oneriri, apart from what is construed as serious interference, or meddling, with farming practices such as herbicide spraying, farmers' complaints about blockholder behaviour centres on what they believe is ignorance or lack of consideration:

Yes, a lot of [blockholders] are keen to learn and they read books. The trouble is that then they try to tell us established farmers what we should be doing. Well, you just have to humour them.

There is conflict when Auckland people buy small blocks up rural roads and then don't respect farmers moving their stock on the road, travelling too fast and creating havoc for the farmer.

They just don't realise that for this community to have such good services, they have to be maintained and people power does that. They have to be involved.

What a person does with their own land is their choice - as long as they're not living off me. If they are on the welfare system and they are able to work then they don't have my respect. If I work I expect every other bugger to work.

We don't mind them riding [horses] over our land but when they leave the gates open I see red. They just don't think.

Blockholders seem to have fewer specific complaints about farmers, though many bemoan the 'acres of cowshit' left on roads by driven stock. Blockholders are more concerned about the reaction of farmers to their presence on the peninsula:

The more people travel overseas the more their eyes are opened to other people's ways of life. These are the people who are much more open to newcomers. Those who haven't travelled much from this peninsula, they are the ones who resist change and resent people with different lifestyles coming in. They are especially suspicious of anything that smacks of 'green' culture.

One farmer said to us 'It's you damn blockies that are causing us to go to extra expense and take extra care because we are so damn scared that we are going to [spray] your trees and things. This has created a bit of a wedge [between farmers and smallholders]. 
I always think the big old farming families have an almost feudal feeling that they own the place. They probably feel that they are losing their status. I think they feel that something has shifted. Well it has: we are all here.

I feel that most [farmers] resent us being here. It was said several times to us: total amazement that we were planting trees. Why do you want to plant those trees? What are you going to do with all this grass? Where are your animals? It was such a new concept for them. They didn't plant trees.

The opening up of Oneriri to new interests has clearly prompted a number of dimensions of dispute and division. Halfacree and Boyle (1998: 8) say such material struggles very much involve contrasting representations of rurality, with various actors attempting to impose their respective representations of the rural over others. This seems to suggest a reason why, as observed by Cloke and Milbourne (1992) such oppositions are culturally based and, therefore, largely symbolic. The pre-existing social and cultural constitution of Oneriri by the farming community as the dominant culture thus becomes a foundation of resistance to rural change from within (Barlow and Cocklin, 2003).

It needs to be pointed out that the marginalisation of blockholders, and feelings on the part of farmers that their way of life is somehow under threat, are conditions that have arisen largely because of the fact that the presence of blockholders in Oneriri has come about only because farmers themselves have permitted it.

The loss of established farming families from the peninsula has been felt keenly by many, and while blockholders are not blamed for their departure, they are seen to have an indirect influence. One farmer regretted the recent premature departure of colleagues and kin, attributing it to the fact that urban migrants' interest in Oneriri meant the farmers were able to 'sell well' and were thus persuaded to sell earlier than they might. Other farmers see this situation differently:

Selling-wise, lifestylers are a good thing. The properties that have already been developed make it more attractive for other townies to come and have a look too. It means that you're going to put your farm on the market with development in mind.

I struggle, generally speaking, with Aucklanders, but we certainly 
need their financial resources. In Oneriri they are the potential lifestylers who will pay the top prices for our land.

Not all farmers feel threatened, however. Some view new people in the district in a positive light, suggesting use of the exclusionary terms 'cockies' and 'blockies' oversimplifies the nature of this social relationship. The following extracts from farmers' narratives show that some are finding reasons to welcome the presence - if not always the persons - of blockholders in Oneriri:

The change has been for the better from my point of view. There is a lot more culture and a lot more interesting people - a lot of artistic people and others with good energy and attitudes. The impact of new blood and subdivision has been a good thing.

I've got nothing against blockholders. You know I quite enjoy a lot of them and I think it's brought a diversity to our community.

The influx of new people I see as a good thing. A lot of rural communities around New Zealand are suffering from depopulation and this area clearly isn't. When farms obviously can't support labour because of declining profitability, well the next obvious choice must be alternative land use, and I suppose subdivision is alternative land use. And is that intrinsically worse than having pine trees over a thousand acres?

Small blockholders have added another dimension to this district. They are a fringe group and can make it quite difficult to farm, but many come in here with resolution. They buy a little bit of land and come up with some marvellous ideas for using that land that somehow the established people would never think of in a hundred years.

The positives are that we are getting a diverse population, a multicultural population. A lot of them have brought good ideas and different ways of doing things into organisations in the community. It isn't just the very narrow, staid little farming community it was where a few families had been here for generations and would never believe that things could be done another way. 
Change usually comes slowly to rural areas. Most changes are small and they take time to become widespread. Farming folk are necessarily conservative and it is the nature of farming that its processes cannot easily be hurried. The deregulation of agriculture in 1984 brought sudden change to the farming sector and its effects can be seen today in Oneriri, as in the rest of New Zealand. The landscape changed as the peninsula's farmers met the demands of international commodity markets: velvety sheep paddocks have given way to a farmscape roughened and torn by bulls. The more obvious manifestation of change is the new houses, dotted on hilltops and ridgelines, that locate migrants from the city, newly settled on the smallholdings subdivided off by farmers.

The newcomers each have their own, sometimes Arcadian, sense of the rural which is generally at odds with the more homogeneous understandings of the use and care of land held by the farmers. These differing views can be seen as cultural constructs arising from differing sets of assumptions, expectations and values (Cloke and Little, 1997). Cordial social relations between Oneriri farmers and blockholders scarcely exist, not solely because of conflict, but also because no community of interest exists. Blockholders can be sympathetic to farmers' concerns, but also criticise them for what they see as poor farming practices. Conflict arises between the two groups where the practice of farming becomes an arena for disputation. The different understandings of rurality result in different behaviours, producing tension. At the most specific level issues revolve around complaints by blockholders about farmers' use of herbicidal sprays, and frequently the noise of stock and the fouling of roads when stock is driven on them. Farmers in their turn complain about weed-infested small blocks, uncontrolled dogs and the lack of consideration townies display when negotiating stock on the roads.

These issues, while specific and frequently aired, can be accounted for by differences between the cultural expectations of both groups. The cultural understandings of urban people, even after they have spent some time in the rural environment, can be seen as a challenge to the farmers who represent the dominant culture on the peninsula. However, it is unlikely these differences will be resolved as long as fresh urban faces continue to appear in the Oneriri landscape. 
NOTES

1 Throughout New Zealand and elsewhere people living on small rural holdings are frequently referred to as 'lifestylers'and their holdings as 'lifestyle blocks'. During the course of my research it became apparent that these terms, though well understood by all participants, were not entirely accurate descriptions. Most farmers refer to the 'lifestyle' offered by farming as their principal reason for being a farmer. Many blockholders see 'lifestyler'as fast becoming a pejorative description, and 'lifestyle'as at least an incomplete term requiring qualification to be fully descriptive of their particular situation. Accordingly, in this paper, the term 'blockholder' is used except where other terms are particularly nominated by participants.

2 The community news sheet circulating in Oneriri reported an incident where wandering dogs were shot. The owner of the dogs reacted by threatening to kill the person responsible for shooting them (Kaiwaka Bugle, 2003).

3 I would like to thank, and acknowledge the forbearance of, the participants in this study, tolerating the presence of an inquisitive social researcher sometimes at short notice. Their transcripts will, with their individual permission, be lodged in the archives of the Kaiwaka Historical Society as a 'snapshot'of this time. My thanks go also to Massey University, Albany, for the one-year thesis scholarship that helped keep the wolf from the door during the final year of my studies.

4 At the time of writing, advertising for a 350-acre block on the peninsula was nominating the number of individual lots the land could carry if bought for development as a farm park, rather than stating its carrying capacity in stock units.

5 The term Arcadia is generally associated with the structure of feeling and sentiment known as 'pastoral' or the 'rural idyll'. Though derived originally from an area in Greece, the mythical Arcadia is a dreamscape which to a greater or lesser extent contrasts with the realities of everyday life (Swaffield and Fairweather, 1998). In this discussion the terms Arcadia and rural idyll are used interchangeably.

6 Despite the decimalisation of land area measurement, both farmers and blockholders used 'acres' rather than 'hectares' when quantifying land. Accordingly, 'acres' is used throughout this paper. 
Barlow, K. and Cocklin, C. 2003 'Reconstructing rurality and community: plantation forestry in Victoria, Australia', Journal of Rural Studies 19:503-519.

Boyle, P. and Halfacree, K. (eds) 1998 Migration into Rural Areas: theories and issues, Chichester, England: John Wiley and Sons.

Boyle, P., Halfacree, K. and Robinson, V. 1998, Exploring Contemporary Migration, Harlow, England: Addison Wesley Longman.

Bryant, C.R., Russwurm, L.H. and McLellan, A.G. 1982, The city's countryside: Land and its management in the rural-urban fringe, London and New York: Longman.

Cloke, P. 1983, An Introduction to Rural Settlement Planning, London and New York: Methven.

Cloke, P. and Little, J. (eds) 1997, Contested Countryside Cultures: otherness, marginalisation and rurality, London: Routledge.

Cloke, P. and Milbourne, P. 1992, 'Deprivation and Lifestyles in Rural Wales - II. Rurality and the Cultural Dimension', Journal of Rural Studies, 8 (4):359371.

Federated Farmers of New Zealand 2002 'Life After Subsidies: The New Zealand Farming Experience' http://www.fedfarm.org.n

Franklin Distrct Council 2003, Proposed Plan Change 14: Part 3 - Principal Resource Management Issues, Pukekohe: Franklin District Council.

Furuseth, O.J. and Lapping, M.B. (eds) 1999 Contested Countryside: The Rural Urban Fringe in North America, Aldershot, England: Ashgate Publishing.

Gouin, D., Jean, N. and Fairweather, J. 1994 New Zealand Agricultural Policy Reform and Impacts on the Farm Sector. Research Report No. 23o, Canterbury: Agribusiness and Economics Research Unit, Lincoln University.

Halfacree, K. and Boyle, P. 1998 'Migration, rurality and the post-productivist countryside', in Boyle, P. and Halfacree, K. Migration Into Rural Areas: theories and issues, Chichester, England: John Wiley and Sons. 
Halseth, G. 1999 'Disentangling policy, governance, and local contention over change in Vancouver's rural urban fringe'in Furuseth, O.J. and Lapping, M.B. (eds) Contested Countryside: The Rural Urban Fringe in North America, Aldershot, England: Ashgate Publishing.

Hughes, A. 1997 'Rurality and "Cultures of Womanhood": Domestic identities and moral order in village life', in Cloke, P. and Little, J. (eds) Contested Countryside Cultures: otherness, marginalisation and rurality, London: Routledge.

Johnsen, S. 2003 'Contingency Revealed: New Zealand Farmers'Experiences of Agricultural Restructuring', Sociologia Ruralis 43 (2):128-153.

Jones, O. 1995 'Lay Discourses of the Rural: Developments and Implications for Rural Studies', Journal of Rural Studies 11 (1):35-49.

Lambert, A. 2003 'Rural Sentimental', Financial Times Magazine, September 6, 2003: 22-25.

Levett, A. and Pomeroy, A. 1997 Managing Social Transformation in Rural New Zealand. MAF Policy Technical Paper 97/20, Wellington: Ministry of Agriculture and Fisheries.

Little, J. and Austin, P. 1996 'Women and the Rural Idyll' Journal of Rural Studies 12 (2): 101-111.

Matthews, H., Taylor, M., Sherwood, K., Tucker, F. and Limb, M. 2000 'Growing Up in the Countryside: Children and the Rural Idyll', Journal of Rural Studies 16:141-153.

Mawhinney, T.J.A. 1974 The Ten Acre Subdivision in Manukau City and Franklin County, unpublished M.A. thesis in Geography, University of Auckland.

Murdoch J. and Day, G. 1998 'Middle class mobility, rural communities and the politics of exclusion', in Boyle, P. and Halfacree, K. (eds) Migration into Rural Areas: theories and issues, Chichester, England: John Wiley and Sons.

Murdoch, J. 1995 'Middle Class Territory? Some remarks on the use of class analysis in rural studies', Environment and Planning 27:1213-1230.

Share, P., Gray, I. And Lawrence, G. 1991 'Rural Society and the Sociology of 
Agriculture: Research Priorities for Rural Sociologists in the 1990s', in Fairweather, J.R. (ed) Proceedings of the Rural Economy and Society Section of the Sociological Association of Aotearoa (N.Z.) Canterbury: Agribusiness and Economic Research Unit, Lincoln University.

Smith, S.P. 2002 [1910] The Peopling of the North: The History of Ngatiwhatua Tribe of Kaipara, Christchurch: Cadsonbury Publications.

Statistics New Zealand 1999 A Regional Profile: Northland, Wellington: Statistics New Zealand.

Swaffield, S. and Fairweather, J. 1998 'In Search of Arcadia: The Persistence of the Rural Idyll in New Zealand Rural Subdivisions', Journal of Environmental Planning and Management 41 (1):111-128.

van Dam, F., Heins, S. and Elbersen, B.S. 2002 'Lay discourses of the rural and stated preferences for rural living. Some evidence of the existence of a rural idyll in the Netherlands', Journal of Rural Studies 18: 461-476.

Waldegrave, C. and Stuart, S. 1998 Family dynamics among urban to rural migrants: a study of households moving out of urban areas in New Zealand; MAF Policy Technical Paper 98/8, Wellington: Ministry of Agriculture and Fisheries.

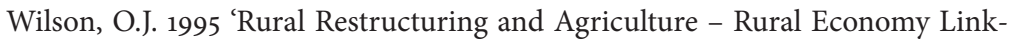
ages: A New Zealand Study', Journal of Rural Studies 11 (4): 417-431. 